DOI 10.18699/SBB-2020-82

\title{
Количественная оценка концентрации хлорофилла $a$ фототрофных микроорганизмов в воде с помощью методов машинного обучения и камеры мобильного телефона
}

Руденко А.П.*, Теслюк А.Б., Мельникова А.А., Намсараев 3.Б.

НИЦ «Курчатовский институт», Москва, Россия

*e-mail: inasty5@mail.ru

Ключевые слова: хлорофилл, фототрофные микроорганизмы, качество воды, машинное обучение

Мотивация и цеель: Проблема массового развития микроорганизмов [1] в водоемах является крайне серьезной и может иметь негативное влияние на экологию и экономику любого региона (гибель обитателей водоема, выход из строя оборудования, снижение туристической привлекательности и т.д.). Кроме того, многие виды микроорганизмов токсичны, а значит вода, в которой концентрация микроорганизмов превышает норму, становится непригодной для использования человеком.

Meтоды $и$ алгоритмы: Основным показателем развития микроорганизмов в воде является концентрация пигментов, в частности, концентрация хлорофилла $a$ в воде. Существуют разные методы определения концентрации пигментов, например, спутниковые [2] или спектрофотометрические методы. Однако данные способы определения концентрации пигментов в пробах воды требуют наличия дорогостоящего оборудования и специалистов. В данной работе разрабатывается инновационное устройство для оценки концентрации хлорофилла $a$ и других пигментов фототрофных микроорганизмов с помощью камеры мобильного телефона и методов машинного обучения. Ключевыми преимуществами данного метода являются низкая себестоимость, простота и доступность технологии, а также мобильность устройства, что позволяет оперативно измерять концентрацию хлорофилла $a$ не отходя от водоема.

Результаты: На текущий момент сконструирован прототип устройства для определения концентрации хлорофилла $a$ в воде, проведены эксперименты с тестовыми культурами, разработана нейронная сеть для предсказания концентрации пигментов фототрофных микроорганизмов. Точность определения концентрации хлорофилла $a$ в ходе экспериментов составила $97 \%$.

Заключение и доступность: В ходе экспериментов было показано, что разрабатываемый метод применим для анализа концентрации хлорофилла $a$ в широком диапазоне значений.

Благодарности: При поддержке программы «УМНИК» Фонда Содействия Инновациям.

Список литературы

1. Namsaraev Z., Melnikova A., Komova A., Ivanov V., Rudenko A., Ivanov E. (2020) Algal Bloom Occurrence and Effects in Russia;12(1):285.

2. Namsaraev Z., Melnikova A., Ivanov V., Komova A., Teslyuk A. (2018) Cyanobacterial bloom in the world largest freshwater lake Baikal;121(3):32-39. 